UDC 657.412.7:330.322

\title{
METHODICAL APPROACH TO FORECASTING THE REAL RETURN ON INVESTMENT IN NON-STATE PENSION FUNDS
}

\section{МЕТОДИЧНИЙ ПІДХІД ДО ПРОГНОЗУВАННЯ РЕАЛЬНОÏ ДОХІДНОСТІ ІНВЕСТИЦІЙ У НЕДЕРЖАВНІ ПЕНСІЙНІ ФОНДИ}

\author{
Zhykharieva Vlada, Parshikova Mariia, Chromih Tetiana \\ Odessa National Maritime University \\ Жихарєва Влада Вікторівна \\ доктор економічних наук, професор, \\ Одеський національних морський університет \\ ORCID: https://orcid.org/0000-0002-2179-8483 \\ Паршикова Марія Валеріївна \\ магістрант, \\ Одеський національних морський університет \\ ORCID: https://orcid.org/0000-0002-7614-6642 \\ Хромих Тетяна Володимирівна \\ магістрант, \\ Одеський національних морський університет \\ ORCID: https://orcid.org/0000-0001-8020-465X
}

In the article the methodical approach to determining the projected real return on investment related to a private pension funds (PPFs) is proposed. The technique involves variant calculations and allows maximization the real return of investor based on the variation of input parameters. The first stage involves building the model for forecast investments in PPF, taking into account compound interest. At the second stage, the calculation of periodic pension benefits is based on the forecast rate of return. At the third stage, an investor, based on the model, can perform the inverse operation - to determine the return on investment without taking into account inflation, using the money-weighted rate of return, based on NPF's proposal for payments. At the fourth stage, the real return on investment is calculated taking into account the inflation rate. The criterion for the choice of investment conditions is the maximum real return on investment. The capitalization rate is compared with the risk-free rate.

Keywords: investments, private pension funds, pension provision, profitability assessment, capitalization rate, math for finance.

Криза системи державного пенсійного забезпечення в Україні й розвиток недержавного пенсійного забезпечення роблять актуальною проблему визначення критеріїв вибору інвестором недержавного пенсійного фронду (НПФ) і умов інвестування. Одним з найважливіших критеріїв $€$ рівень реальної ставки капіталізації вкладень у пенсійний фронд. 3 урахуванням цього, метою статті є розробка методичних підходів до визначення і максимізації реальної прогнозної дохідності інвестицій з погляду вкладника у НПФ. Основою дослідження $€$ наукові праці з питань функціонування НПФ, методологія інвестиційного менеджменту, методичні засади фрінансової математики (концепція вартості грошей у часі, нарахування складних відсотків, дисконтування, урахування інфляції), метод варіантних розрахунків. У статті запропонована методика визначення реальної дохідності інвестицій, пов'язаних з інвестуванням у НПФ, яка включає чотири етапи. Перший етап передбачає побудову моделі прогнозних періодичних вкладень у пенсійній фонд з урахуванням складних відсотків. На другому етапі здійснюється розрахунок періодичних пенсійних виплат на основі прогнозного показника дохідності. На третьому етапі інвестор на основі моделі може виконати зворотну операцію - визначити прибутковість інвестицій без урахування інфрляції, використовуючи зважену грошову прибутковість, на основі пропозиції НПФ по виплатах. На четвертому етапі розраховується реальна дохідність інвестицій з урахуванням темпу інфляції. Критерієм вибору інвестором НПФ і умов інвестування є максимальна реальна дохідність 
інвестицій. Отримана ставка капіталізації порівняється з безризиковою ставкою. Методика передбачає виконання варіантних розрахунків і дозволяє максимізувати реальну дохідність інвестора на основі варіювання вхідних параметрів - періодів вкладення грошей і отримання пенсії, періодичності й суми інвестицій, рівня бажаних пенсійних виплат. Практична цінність підходу полягає у можливості зробити прогноз реальної дохідності інвестицій з погляду інвестора, на основі грошових потоків, пов'язаних з вкладеннями у НПФ і пенсійними виплатами, з метою вибору НПФ і умов інвестування.

Ключові слова: інвестиції, недержавні пенсійні фронди, пенсійне забезпечення, оцінка дохідності, ставка капіталізації, фрінансова математика.

В статье предлагается методика определения прогнозной реальной доходности инвестиций в негосударственные пенсионные фонды (НПФ). Методика включает вариантные расчеты и позволяет максимизировать доходность инвестора за счет изменения входных параметров. На первом этапе строится модель прогноза инвестиций в НПФ с учетом сложных процентов. На втором этапе рассчитываются пенсионные выплаты на основе прогнозной доходности. На третьем этапе инвестор на основе модели может выполнить обратную операцию - определить доходность инвестиций без учета инфляции, используя взвешенную денежную доходность, на основе предложения НПФ по выплатам. На четвертом этапе рассчитывается доходность инвестиций с учетом уровня иноляции. Критерием выбора условий инвестирования является максимальная реальная отдача от вложений. Ставка капитализации сравнивается с безрисковой ставкой.

Ключевые слова: инвестиции, негосударственные пенсионные фонды, пенсионное обеспечение, оценка доходности, ставка капитализации, фринансовая математика.

Formulation of the problem. The crisis of the state pension system in Ukraine and development of the non-state pension segment make it very important to determine the criteria that an investor can use to select a private pension fund (PPF) and investment conditions. One of the most important criteria is the level of the real capitalization rate of investments in PPF. Therefore, an important task is to develop methodical approach to determining and maximizing the real projected return on investment from the point of view of a PPF investor.

Analysis of recent research and publications. The largest pension funds in the world were studied by the Thinking Ahead Institute in a Joint study with Pensions \& Investments $[1$, p. 7$]$. Funds from the Asia-Pacific region have shown the largest growth in recent years. The share of Latin America, Africa and Europe has also increased. Despite the declining share of North America, it remains the largest region in terms of value and number of funds.

The dynamics of growth of pension fund assets is also considered in the OECD study Pension Funds in Figures. Private and corporate funds accounted for a total of $32 \%$ of assets [2, p. 1].

In [3] the mechanism of PPFs and their types are considered. Defined benefit (DB) finds guarantee a certain amount of pension, for example, as a percentage of wages before retirement. But since the future is unknown, it requires many assumptions: life expectancy, wage growth and future inflation. If the assumptions are not justified, the size of the fund's assets may differ from the size of its pension liabilities. Therefore, investment risks are borne by the sponsor, not the investor. In recent years, the popularity of $D B$ funds has been declining, while there are more defined contribution (DC) pension funds. They have a certain amount of contributions, and each investor receives as much as his investment account will earn. Therefore, the sponsor usually offers investors a choice of several investment strategies or managers. But in fact the investment risks will be borne by the investor.

In the work of O. V. Martsenyuk-Rozaryonova \& O. A. Ozvenchuk the state of private pension provision in Ukraine is analyzed [4]. The article by M. O. Konina \& K. H. Reha identifies the main obstacles to development and ways to overcome them in Ukraine [5, p. 653]. Sections of some publications are also devoted to this issue, for example, in the work of S. O. Kropelnytska, T. V. Solodzhuk [6, p. 159], a few complex studies, for example, an article by N. A. Tsikanovska, which contains the classification of PPFs [7, p. 67].

Some aspects of the analysis of PPFs and their profitability were paid attention by such researchers as S. M. Prilipko, R. P. Boychuk \& S. V. Glibko [8, p. 223], T. O. Khlybova \& K. P. Chernenok [9, p. 487], Yu. V. Sokorinsky [10, p. 135], I. E. Janul [11, p. 26] and others.

Selection of previously unsolved parts of the problem. According to the analysis of sources, scientists consider mainly the types of classification of PPFs, the problems of their development and methods of overcoming these problems. But there are no methodological approaches to determine and maximize the projected real return on investment in PPFs, which is an important task for investors.

Formulation of the goals of the paper. The article develops a methodical approach to 
determining and maximizing the projected real return on investment in private pension funds from the point of view of investor, based on the variation of different investment conditions.

Presentation of the main research material. As of March 31, 2020, 63 PPFs were registered in Ukraine, among which it should be noted: Corporate Pension Fund of the NBU, Corporate Pension Fund of Ukreximbank, Open PPF PrivatFund, OTP Pension, Reliable Perspective, Pension Capital, Ukrainian Pension Union, Pension Savings Fund, Free Flight, Initiative Ukrainian Pension Contract, Golden Autumn, Decent Life, etc. The total value of PPFs' assets as of March 31, 2020 amounted to UAH 3,106.5 million. More than 878.3 thousand people are participants of PPFs. Funds are actively fulfilling their main purpose and paying pensions to participants. As of March 31, 2020, PPFs paid more than UAH 986.7 million in pensions [12].

Non-state pension funds, which received the highest returns (TOP 10), are shown in Figure 1.

As can be seen from the data, the yield of the TOP 10 non-state pension funds ranged from $8.23 \%$ to $17.25 \%$, i. e. the variance of return was very large.

How much a depositor will save for retirement depends on where and how successfully the asset management company will invest the money. If the asset management company pursues a prudent policy and chooses highly profitable instruments, the capital of PPF participants may increase significantly.

The amount of pension contributions is determined by the depositor and it can be fixed. Each fund offers different conditions. Sometimes to change the size or «freeze» contributions you need to notify the administrator in a month. In addition, the fund has the right to set a minimum limit - for example, pension contributions of at least $10 \%$ of the minimum wage.

The frequency is also different: once, once a year or six months, quarterly, monthly. Some funds allow clients to suspend contributions for a long period, others may exclude participants for inactivity and pay money after the client reaches retirement age.

An important criterion for choosing a PPF is profitability, taking into account the duration of the investment with a horizon of 10-40 years, so it is important stability and reliability in the long-term aspect, rather than high instantaneous profitability. High income is directly associated with high risk.

Usually PPFs offer the investor to choose the period of investment and pension and the amount of periodic investments or the projected level of payments. An important task of the investor is to

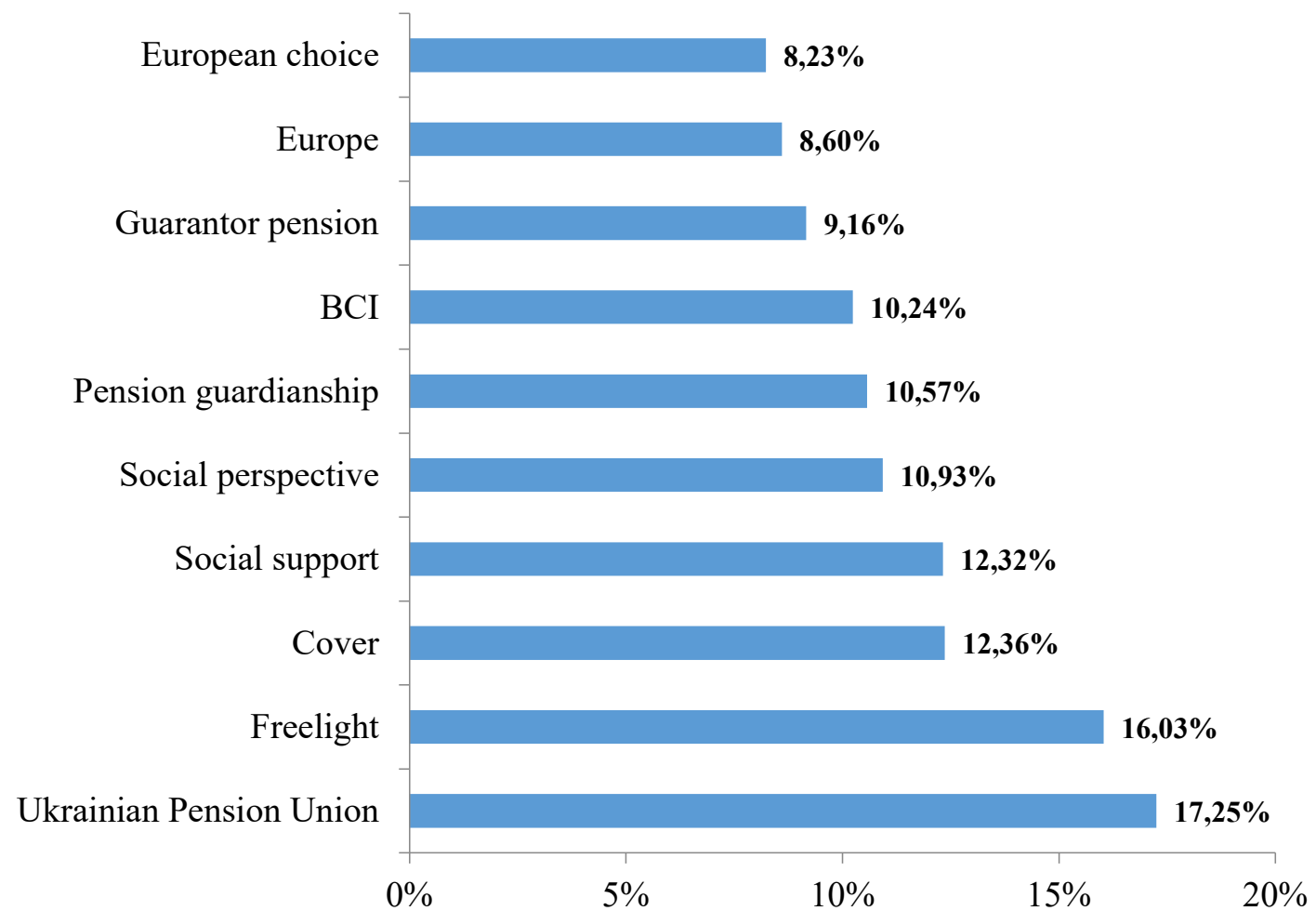

Figure 1. TOP 10 non-state pension funds received the highest yield in 2020, \% Source: compiled by authors based on data of the Ukrainian Association of Pension Fund Administrators 
forecast the real return on investment based on cash flows associated with investments in PPFs and pension benefits. The following methodical approach is proposed to determine the real return on investment associated with investing in PPFs, which includes four stages.

At the first stage, it should build an Excel model of forecast periodic investments in the pension fund. Interest is accrued by the pension fund on the basis of compound interest. Consider this as an example: a 45-year-old person plans to contribute to a private pension fund for at least another 10 years. The amount of monthly pension contributions is $\mathrm{UAH} 2,000$. It is planned to receive a pension for 20 years. The average projected annual return on pension assets in a private pension fund is $13 \%$. We calculate the amount of investor's investments based on the forecast level of profitability of the selected private investment fund (Table 1). Calculations are made on an annualized basis. The accumulated amount at the end of the 10th year will be: UAH 499,543.60.

In the second stage, the calculation of periodic pension payments is based on the forecast money-weighted rate of return (MWRR). This type of rate is used by investment funds, when the time of deposit and return of funds are determined. Based on the predicted MWRR of $13 \%$, in the Table 2 the forecast periodic pension payments to the depositor are defined.

The estimated annual amount that will be paid to the investor by the pension fund for 20 years is UAH 116,478.72. The total amount that will be paid to the investor by the pension fund for 20 years is UAH 2.329574 million. Every month the investor receives a pension from PPF UAH 9,707.

At the third stage, knowing the proposed PPF level of annual investment and pension payments, the investor can determine return on investment in the pension fund without taking into account inflation based on the MWRR, solved the equation:

$$
-\sum_{t=1}^{n} \frac{V_{t}+P R_{t}}{(1+M W R R)^{t}}+\sum_{t=n+1}^{T} \frac{P_{t}}{(1+M W R R)^{t}}=0 .
$$

where

$V_{t}$ - is the amount of annual investment in year t, UAH;

$P R_{t}$ - the amount of compound interest in year $\mathrm{t}, \mathrm{UAH}$; UAH.

$P_{t}$ - the amount of pension benefits in year $t$,

Money-weighted rate of return is calculated as the internal rate of return or discount rate at which the sum of the present value of all cash flows on the investment is zero.

At the fourth stage, to take into account the rate of inflation, it is necessary to calculate the real return on investment using the Fisher formula. For our example, with an average projected inflation rate $(\mathrm{t})$ of $10 \%$ per year, the real return on investment in PPF:

$$
\mathrm{MWRR}_{\text {real }}=\frac{M W R R-\mathrm{t}}{1+\mathrm{t}}=\frac{0,13-0,10}{1,10}=2,73 \% .
$$

The criterion for the investor to choose a PPF and investment conditions will be the maximum real return on investment, which is achieved on the basis of variation of investment conditions:

$$
\mathrm{MWRR}_{\text {real }} \rightarrow \max \text {. }
$$

Further, it is recommended to compare the obtained capitalization rate with the risk-free rate, which in Ukraine for investments in UAH can be determined on the basis of the return on bank deposits or the return on real estate investments.

Calculation of the amount of annual investments in PPF, UAH

\begin{tabular}{|c|c|c|c|}
\hline Year & $\begin{array}{c}\text { Balance at the beginning } \\
\text { of the year }\end{array}$ & Interest & $\begin{array}{c}\text { Balance at the end } \\
\text { of the year }\end{array}$ \\
\hline 1 & 24000,00 & 3120,00 & 27120,00 \\
\hline 2 & 51120,00 & 6645,60 & 57765,60 \\
\hline 3 & 81765,60 & 10629,53 & 92395,13 \\
\hline 4 & 116395,13 & 15131,37 & 131526,49 \\
\hline 5 & 155526,49 & 20218,44 & 175744,94 \\
\hline 6 & 199744,94 & 25966,84 & 225711,78 \\
\hline 7 & 249711,78 & 32462,53 & 282174,31 \\
\hline 8 & 306174,31 & 39802,66 & 345976,97 \\
\hline 9 & 369976,97 & 48097,01 & 418073,98 \\
\hline 10 & 442073,98 & 57469,62 & 499543,60 \\
\hline
\end{tabular}


Table 2

Calculation of periodic pension benefits based on the forecast MWRR, UAH

\begin{tabular}{|c|c|c|c|c|}
\hline Year & Cash flow & Discount factor & $\begin{array}{l}\text { Discounted cash } \\
\text { flow }\end{array}$ & $\begin{array}{c}\text { Cumulative } \\
\text { discounted cash } \\
\text { flow }\end{array}$ \\
\hline 1 & $-27120,00$ & 0,8846 & $-23990,79$ & $-23990,79$ \\
\hline 2 & $-30645,60$ & 0,7826 & $-23981,58$ & $-47972,37$ \\
\hline 3 & $-34629,53$ & 0,6923 & $-23972,38$ & $-71944,75$ \\
\hline 4 & $-39131,37$ & 0,6124 & $-23963,18$ & $-95907,93$ \\
\hline 5 & $-44218,44$ & 0,5417 & $-23953,98$ & $-119861,91$ \\
\hline 6 & $-49966,84$ & 0,4792 & $-23944,79$ & $-143806,70$ \\
\hline 7 & $-56462,53$ & 0,4239 & $-23935,60$ & $-167742,29$ \\
\hline 8 & $-63802,66$ & 0,3750 & $-23926,41$ & $-191668,70$ \\
\hline 9 & $-72097,01$ & 0,3317 & $-23917,23$ & $-215585,93$ \\
\hline 10 & $-81469,62$ & 0,2935 & $-23908,05$ & $-239493,98$ \\
\hline 11 & 116478,72 & 0,2596 & 30237,78 & $-209256,20$ \\
\hline 12 & 116478,72 & 0,2297 & 26748,83 & $-182507,37$ \\
\hline 13 & 116478,72 & 0,2032 & 23662,44 & $-158844,93$ \\
\hline 14 & 116478,72 & 0,1797 & 20932,18 & $-137912,75$ \\
\hline 15 & 116478,72 & 0,1590 & 18516,94 & $-119395,81$ \\
\hline 16 & 116478,72 & 0,1406 & 16380,39 & $-103015,42$ \\
\hline 17 & 116478,72 & 0,1244 & 14490,35 & $-88525,06$ \\
\hline 18 & 116478,72 & 0,1101 & 12818,40 & $-75706,66$ \\
\hline 19 & 116478,72 & 0,0974 & 11339,36 & $-64367,30$ \\
\hline 20 & 116478,72 & 0,0861 & 10030,98 & $-54336,32$ \\
\hline 21 & 116478,72 & 0,0762 & 8873,57 & $-45462,74$ \\
\hline 22 & 116478,72 & 0,0674 & 7849,70 & $-37613,04$ \\
\hline 23 & 116478,72 & 0,0596 & 6943,97 & $-30669,07$ \\
\hline 24 & 116478,72 & 0,0527 & 6142,75 & $-24526,32$ \\
\hline 25 & 116478,72 & 0,0467 & 5433,98 & $-19092,34$ \\
\hline 26 & 116478,72 & 0,0413 & 4806,98 & $-14285,36$ \\
\hline 27 & 116478,72 & 0,0365 & 4252,34 & $-10033,02$ \\
\hline 28 & 116478,72 & 0,0323 & 3761,68 & $-6271,34$ \\
\hline 29 & 116478,72 & 0,0286 & 3327,65 & $-2943,69$ \\
\hline 30 & 116478,72 & 0,0253 & 2943,69 & 0 \\
\hline
\end{tabular}

Source: calculated by authors

Conclusions. The main types of PPFs guarantee a certain amount of pension, for example, as a percentage of wages before retirement, and funds that have a certain amount of contributions, and each investor receives as much as his investment account will earn, while the investment risks are borne by the depositor.

The analysis showed that the yield of the TOP 10 PPFs of Ukraine ranged from $8 \%$ to $17 \%$ in 2020 , i. e. the spread of values was very large.

The main criterion for choosing a PPF is the return, taking into account the duration of the investment with a horizon of 10-40 years, so stability and reliability in the long run are important. It is important for the investor to forecast the real return on investment based on the cash flows associated with investments in PPF and pension benefits. The proposed methodical approach of determining the real return on investment associated with investing in PPF includes four stages.

The first stage involves building a model of projected periodic investments in the pension fund, taking into account compound interest.

At the second stage, the calculation of periodic pension benefits is based on the forecast money-weighted rate of return.

At the third stage, an investor, based on the model, can perform the inverse operation - knowing the proposed PPF level of annual investment and pension benefits to determine the return on investment without taking into account inflation, using the money-weighted rate of return. 
At the fourth stage the real return on investment is calculated to take into account the inflation rate. The criterion for the investor to choose a PPF and investment conditions will be the maximum real return on investment, which is achieved on the basis of variation of investment conditions. The yield (capitalization rate) is compared with the risk-free rate.

The methodical approach involves the implementation of variant calculations and allows investor to maximize the real return on the basis of variation of input parameters periods of holding money and receiving a pension, the frequency and amount of investment, the level of desired pension benefits. The practical value of the approach is the ability to forecast the real return on investment from the investor's point of view, based on the cash flows associated with investments in PPF and pension benefits, in order to select PPF and investment conditions.

Further research is needed on other criteria for selecting PPFs by depositors, which include independence, professionalism and impeccable reputation of service companies, profitability taking into account the duration of investment with a horizon of $10-40$ years, stability and reliability in the long run, number of fund participants and dynamics its changes, investment strategy or investment portfolio.

\section{REFERENCES:}

1. Global top 300 pension funds: Joint study with Pensions \& Investments. Retrieved September 10, 2021. Retrieved from: https://www.thinkingaheadinstitute.org/content/uploads/2020/11/TAI_PI300_2020.pdf

2. Pension Funds in Figures. Retrieved October 4, 2021. Retrieved from: https://www.oecd.org/pensions/privatepensions/Pension-Funds-in-Figures-2020.pdf

3. Hohlov, V., Samko, S. \& Sobolev, O. (2020) Osnovi finansiv ta investicii [Fundamentals of Finance and Investment]. Retrieved from: https://courses.prometheus.org.ua (in Ukrainian)

4. Marcenyuk-Rozar'onova, O. V. \& Ozvenchuk, O. A. (2018) Stan ta perspektivi rozvitku nederjavnogo pensiinogo strahuvannya $v$ Ukraini [Status and prospects of development of private pension insurance in Ukraine]. Derjavne upravlinnya: udoskonalennya ta rozvitok - Public administration: improvement and development, 10. Retrieved from: http://www.dy.nayka.com.ua/pdf/10_2018/24.pdf (in Ukrainian)

5. Konina, M. O. \& Reha, K. H. (2017) Nederjavne pensiine strahuvannya v Ukraini: pereshkodi rozvitku ta shlyahi ih podolannya [Private pension insurance in Ukraine: obstacles to development and ways to overcome]. Molodii vchenii - Young scientist, 12, 651-654. (in Ukrainian)

6. Kropel'nic'ka, S. O. \& Solodjuk, T. V. (2013) Social'ne strahuvannya [Social insurance]: navch. posib [textbook]. Kyiv: Centr uchbovoi literatury, 336 p. (in Ukrainian)

7. Cikanovs'ka, N. A. (2016) Klasifikaciya nederjavnih pensiinih fondiv u konteksti zabezpechennya inn'oi finansovoi bezpeki [Classification of non-state pension funds in the context of ensuring their financial security]. Visnik Universitetu bankivs'koi spravi - Bulletin of the University of Banking, 12, 64-70. (in Ukrainian)

8. Prilipko, S. M., Boichuk, R. P. \& Glibko, S. V. (2014) Teoretichni zasadi pravovogo regulyuvannya investuvannya innovaciinogo rozvitku $\vee$ Ukraini [Theoretical bases of legal regulation of investment of innovative development in Ukraine]: monografiya [monograph]. Kharkiv: Pravo, 480 p. (in Ukrainian)

9. Hlibova T. O., Chernenok K. P. (2017) Rozvitok nederjavnih pensiinih fondiv v Ukraini [Development of private pension funds in Ukraine]. Molodii vchenii - Young scientist, 7, 486-490. (in Ukrainian)

10. Sokorins'kii, Yu. V. (2018) Vidi nederjavnih pensiinih fondiv [Types of private pension funds]. Yuridichnii byuleten' - Legal Bulletin, 7, 1, 131-137. (in Ukrainian)

11. Yanul', I. E. (2013) Nederjavne pensiine zabezpechennya v Ukraini: problemi ta perspektivi rozvitku [Private pension provision in Ukraine: problems and prospects of development]. Visnik Kyivs'kogo nacional'nogo universitetu imeni Tarasa Shevchenka. Seriya «Ekonomika» - Bulletin of Taras Shevchenko National University of Kyiv. Economics series, 135, 25-27. (in Ukrainian)

12. Administrator nederjanih pensiinih fondiv [Administrator of private pension funds]. Retrieved October 4, 2018. Retrieved from: https://www.npf.com.ua (in Ukrainian)

\section{СПИСОК ВИКОРИСТАНИХ ДЖЕРЕЛ:}

1. Global top 300 pension funds : Joint study with Pensions \& Investments. URL: https://www.thinkingaheadinstitute.org/ content/uploads/2020/11/TAI_PI300_2020.pdf (дата звернення: 02.10.2021).

2. Pension Funds in Figures. URL: https://www.oecd.org/pensions/private-pensions/Pension-Funds-inFigures-2020.pdf (дата звернення: 01.10.2021). 
3. Хохлов В., Самко С., Соболев О. Основи фінансів та інвестицій. URL: https://courses.prometheus.org.ua (дата звернення: 03.10.2021).

4. Марценюк-Розарьонова О. В., Озвенчук О. А. Стан та перспективи розвитку недержавного пенсійного страхування в Україні. Державне управління: удосконалення та розвиток. 2018. Вип. 10. URL: http://www.dy.nayka.com.ua/pdf/10_2018/24.pdf

5. Коніна М. О., Реха К. Х. Недержавне пенсійне страхування в Україні: перешкоди розвитку та шляхи їх подолання. Молодий вчений. 2017. № 12. С. 651-654.

6. Кропельницька С. О., Солоджук Т. В. Соціальне страхування : навч. посіб. Київ : Центр учбової літератури, 2013. 336 c.

7. Цікановська Н. А. Класифрікація недержавних пенсійних фрондів у контексті забезпечення їхньої фінансової безпеки. Вісник Університету банківської справи. 2016. № 12. С. 64-70.

8. Прилипко С. М., Бойчук Р. П., Глібко С. В. Теоретичні засади правового регулювання інвестування інноваційного розвитку в Україні : монограсрія. Харків : Право, 2014. 480 с.

9. Хлибова Т.О., Черненок К.П. Розвиток недержавних пенсійних фондів в Україні. Молодий вчений. 2017. № 7. C. $486-490$.

10. Сокоринський Ю. В. Види недержавних пенсійних фондів, Юридичний бюлетень. 2018. Вип. 7. 4. 1. С. $131-137$.

11. Януль І. Є. Недержавне пенсійне забезпечення в Україні: проблеми та перспективи розвитку. Вісник Київського національного університету імені Тараса Шевченка. Серія «Економіка». 2013. Вип. 135. С. 25-27.

12. Адміністратор недержаних пенсійних фондів. URL: https://www.npf.com.ua (дата звернення: 03.10.2021). 